\title{
Research on Esotericism in Scandinavia
}

\section{Introduction}

The title of this paper can be understood in two senses. In the sense of 'research on esotericism carried out by Scandinavian scholars', the field is blossoming. Several dozen individuals, at various points in their academic careers, are pursuing research on some aspect of Western esotericism however the concept is defined. In the other conceivable sense, 'research on Scandinavian esotericism', the availability of academic studies is generally more limited.

Roughly speaking, the literature on Scandinavian esotericism comprises the same textual genres as the literature on esotericism internationally. There is a considerable corpus of apologetic texts, written by practitioners. There is a polemical literature, written from anti-cult and Christian perspectives. Finally, there is an academic literature with some major strengths, and some equally major lacunae. Some periods and currents are well represented, with a long tradition of historical research that goes back to the early twentieth century. Other currents are blank spots on the scholarly map. Furthermore, nearly all of this literature is composed in local languages, and is therefore inaccessible to an international audience. The situation is reflected in the standard reference work on esotericism, the Dictionary of Gnosis and Western Esotericism. Swedenborg is covered in a full-length article. Apart from this, however, esotericism in Scandinavia is barely mentioned.

Although an increasing number of Scandinavian scholars are researching various aspects of Western esotericism, the discipline is in its infancy in Scandinavia and there are currently no academic positions targeted specifically at specialists in esotericism at any Scandinavian university. However, undergraduate courses in esotericism are beginning to be offered at various universities, such as Stockholm University, Högskolan Dalarna, and at the University of Copenhagen. There is also an increasing number of BA and MA level papers being written (particularly in the History of Religions) which deal with various as- 
pects of esotericism; this is an indication that Western esotericism appears to be a popular subject among students. This popularity among students probably accounts for the fact that a number of students, particularly from Norway and Denmark, have pursued MA studies at the Centre for the History of Hermetic Philosophy and Related Currents, at the Universiteit van Amsterdam (UvA), and in addition to this, three Scandinavian researchers have spent longer periods of time at the Centre as visiting scholars.

The purpose of the present article is to survey the state of the art of this research field, especially pertaining to esotericism in Sweden (the country we are most familiar with), and to provide a rough map of the Scandinavian-language literature, especially for the benefit of nonScandinavian readers.

\section{Esotericism in the Early Modern Age}

Most of the scholars who have dealt with esotericism in the Early Modern Age can be described as specialists on specific currents in the sense that the subjects of their research are not placed in a larger context, but are rather studied as independent phenomena. In the last few years, however, the trend has changed towards a more 'generalist' approach in which the subjects at hand are studied from a broader perspective, concretised by basic research paradigms (e.g. those formulated by Antoine Faivre, Wouter Hanegraaff, and Kocku von Stuckrad). Thus earlier research on topics such as alchemy, astrology, and magic often treated the subjects as something disconnected from the wider intellectual and cultural milieus in which they were being practiced. New research tends to criticise this approach and instead often emphasises the interrelationship of the subject with its context. An illustrative example of this new approach is Carl-Michael Edenborg's thesis Alkemins skam: den alkemiska traditionens utstötning ur offentligheten (The Shame of Alchemy: the Expulsion of the Alchemical Tradition from the Public Sphere), published in 2002. In his thesis Edenborg questions the assumption that alchemy disappeared from the scene at the end of the eighteenth century due to the emergence of modern chemistry. Instead, modernity itself is identified as the reason for the waning of alchemy. The thesis analyses the main discourses (such as ridicule and shaming) whereby alchemy was expelled from the public sphere, as well as the strategies developed by alchemists themselves to combat this expulsion. 
Other works that have a more general approach to esotericism is Susanna Åkerman's research on the Swedish Queen Christina and the Rosicrucian movement in Scandinavia, particularly her book Rose Cross over the Baltic: the Spread of Rosicrucianism in Northern Europe (1998). Jole Shackelford and his research on Paracelsism in Scandinavia should also be mentioned. Perhaps not very surprisingly, both Rosicrucianism and Paracelsism in Scandinavia reflected the way in which these currents had developed on the Continent, particularly in the German-speaking world. It is thus perhaps a bit misleading to speak of a 'Rosicrucian movement' during the seventeenth century in Scandinavia since no Rosicrucian organisation existed at that time. Instead, Rosicrucianism was spread through a number of loosely formed networks consisting of individuals with an interest in the Rosicrucian manifestos and the teachings connected to these.

Apart from Emanuel Swedenborg-who has received wide international attention from a long line of scholars-the individual with perhaps the greatest influence on Swedish esotericism in the early modern age was Johannes Bureus (1568-1652). He developed his own particular form of Swedish esotericism, mixing runes, Old Norse myths, kabbalah, astrology, Hermeticism and magic into a system that Bureus called Adulruna or Gothic Kabbalah. This system has been thoroughly explored by Thomas Karlsson in Adulrunan och den götiska kabbalan (2005). Karlsson is currently finishing his doctoral thesis on Bureus at Stockholm University.

The eighteenth century saw the proliferation of numerous secret or initiatory societies throughout Scandinavia. A vast amount of literature has been published on the subject, but unfortunately this consists mainly of either polemical anti-Masonic literature, or apologetic literature produced by Masons themselves. The largest and most significant of these societies was the Order of Freemasonry, which in Scandinavia went through an intense esoteric period between 1770 and 1810. Esoteric currents and practices such as ritual magic, alchemy, kabbalah, astrology and Christian theosophy set their mark on the rituals of initiation at that time, and various esoteric quasi-Masonic organisations sprung up, which were regarded by their members as inner orders of Freemasonry.

By the early 1780s Duke Charles had gathered around him a small circle of esotericists including persons such as Gustav Adolph Reuterholm (1756-1813), Johan Gabriel Oxenstierna (1750-1818), Adolf Fredrik Falkenberg af Trystorp (1745-1802), Carl Björnberg (1735-90), and at a later stage Carl Adolf Boheman (1764-1831). This group functioned, 
to a certain extent, as an inner and highly secret elite within Swedish Freemasonry. This can be ascertained from the fact that many of the members of this small circle received the highest degrees of Freemasonry directly from Duke Charles himself in his private sanctuary at the Royal Palace, without having to go through the preliminary St John and St Andrew degrees. Perhaps the most prominent figure in this secret cabal was the obscure Gustaf Björnram (1743-1801) who entered the scene in 1780 as an apprentice of the arcane sciences. The form of magic that Björnram performed was chiefly concerned with communicating with beings in other spheres, such as angels and spirits, and his modus operandi resembles that of the spiritualism of the nineteenth century. A manuscript written by Reuterholm, 'Record of Magical Workings' (Magisk Arbets Iornal, författad af G[ustaf] A[dolph] R[euterholm]: MS. 121.44, Library of the Swedish Order of Freemasonry), written around 1783/4, gives a unique picture of the sort of esoteric activities which occupied Reuterholm and his fellow magicians at the Swedish court at the time.

Other esoteric orders active in Sweden at this time included Metatron and $D-E-L-U$. The first of these two orders was probably founded as early as (or before) the 1740s. According to a few surviving manuscripts (now in the archives of the Swedish Grand Lodge), Metatron was a hermetic-kabbalistic order that was critical of the Order of Freemasonry, which they considered to have revealed too much of the arcane sciences. The name Metatron indicates that the society belonged to an apocalyptic-enochian tradition that dealt with the communication with higher beings, such as angels. D-E-L-U, or The Elect of the Eternal Light (Det Eviga Ljusets (tvalde) was founded by the Mason and esotericist Carl Adolf Boheman in 1802. Boheman was, for a number of years, the confidant of Duke Charles, and shared his interest in magic, alchemy, kabbalah and high degree Freemasonry. $D-E-L-U$ differed from more traditional forms of Freemasonry in that it accepted both men and women-something which remains unacceptable in most Masonic systems to this day. The symbolism of the rituals was taken from alchemy and Christian kabbalah, and although the organisation existed for only a short period of time at least two lodges were founded, the Yellow Rose and the White Rose. The purpose of the organisation appears to have been to create an inner order of Freemasonry in Scandinavia. Apart from a few articles and BA and MA level papers, there exists no modern scholarly research on these forms of esotericism in Sweden.

The scant academic research on Freemasonry in Sweden has to a large extent been dominated by 'the Lamm paradigm', a paradigm associated with the literary historian Martin Lamm and his influential work 
Upplysningstidens romantik (The Romanticism of the Enlightenment), published in 1918-20. In this work Lamm described Freemasonry and similar initiatory societies as expressions of an irrational undercurrent that was in opposition to the ideals and principles of the Enlightenmentand influential Masons such as Gustav Adolph Reuterholm and King Charles XIII were seen as the 'enemies of the light'. It is only in recent years that this polemical and over-simplified view of Freemasonry and Western esotericism has begun to be questioned. For instance, the Finnish historian of ideas Henrik Stenius dealt with Freemasonry as part of the development of the bourgeoisie in his thesis Frivilligt, jämlikt, samfällt: Föreningsväsendets utveckling i Finland fram till 1900-talets början med speciell hänsyn till massorganisationsprincipens genombrott (Voluntary, Equal, United: The development of associations in Finland up to the 20th century with special emphasis on the emergence of the mass-organisation principle, Helsingfors, 1987). A similar approach was adopted by Anders Simonsen in his thesis Bland hederligt folk-organiserat sällskapsliv och borgerlig formering $i$ Göteborg 1755-1820 (Amongst the Honest - Social Life Organised by the People and Bourgeoisie in Göteborg 1755-1820, Göteborg, 2001) in which he analysed a number of initiatory and social societies at a local level. In his thesis Svenska Pommern - kulturmöten och identifikation 1720-1815 (Swedish Pomerania - Cultural Encounters and Identification 1720-1815, Lund, 2003) Andreas Önnerfors discussed the role of Masonic lodges as platforms for social interaction between Swedes and Germans in Swedish Pomerania. In the same year one of the present authors, Henrik Bogdan, defended his thesis From Darkness to Light: Western Esoteric Rituals of Initiation in which he analysed the development of Masonic rituals of initiation from the early 1700s to the 1950s. In 2004 Önnerfors and Bogdan arranged the first academic conference on Freemasonry ever to be held in Sweden. This conference, called 'Between Mysticism and Power Politics: Swedish Freemasonry and the European Enlightenment', was held at Lund University, with the participation of leading scholars in the field from all over Europe. Önnerfors has also created an online database listing Swedish Freemasons from the eighteenth century; the database includes over 4,300 names.

\section{Esotericism since the Early Nineteenth Century}

When perusing literature on esotericism in the last two centuries, one gets the impression that Scandinavia is a geographic and cultural periphery. 'Scandinavian esotericism' is to a large extent an adaptation of 
currents that have arisen abroad. Perhaps surprisingly, the relatively few local innovations that exist are extremely poorly documented. Arguably, the most significant Scandinavian-based currents are the work of Martinus, hylozoics, the Linbu movement, and the Dragon Rouge movement. English-language literature on the first three is almost non-existent; the last is documented in one doctoral thesis.

The most influential Scandinavian esotericist after Swedenborg is probably the Dane Martinus Thomsen (1890-1981), generally known only by his given name Martinus. Biographical passages in his works and in the writings of his followers relate how Martinus, at the age of 31, experienced an expansion of his consciousness, allowing him to formulate a vast and comprehensive account of the spiritual evolution of all living entities in the world. For the remainder of his life, Martinus was an active writer and lecturer. His collected works comprise approximately forty publications, including Livets bog (Book of Life, 7 volumes published between 1932 and 1960). Apart from an article or two in Danish, and two unpublished Master's theses, existing literature on Martinus is overwhelmingly partisan in nature.

Hylozoics is a movement (or technically, an audience cult) inspired by a theosophical worldview. The founder of hylozoics was Henrik von Zeipel (1882-1971), who wrote under the pseudonym Henry T. Laurency. Von Zeipel's books are distributed by the Henry T. Laurency Publishing Foundation, led by Lars Adelskogh (b. 1950). Adelskogh has been accused of anti-Semitism, allegations which have made hylozoics a controversial movement. Adelskogh has published Swedish-language translations of David Icke's conspiracy-based books and has himself written on revisionist history. Although Laurency's books are readily available, there is very little literature on his works, or on hylozoics in the contemporary religious landscape, and to our knowledge there are no scholarly studies at all.

The Linbu movement is a small new religious movement based on the teachings of the Norwegian Hallstein Farestveit. The rather secretive movement is mainly represented in Sweden. Core members live a communal life, and follow a way of living that is said to combine Christian ideas with the teachings of Gurdjieff. Again, there is very little information to be obtained regarding this movement.

Whereas the four currents presented above represent the most locally innovative forms of Scandinavian esotericism in the post- 1800 period, a much broader palette consists of forms of esotericism that are international in scope and which have been adopted with varying modifications in a local, Scandinavian context. Although there is substantially 
more literature on such currents originating in other countries or modelled on esoteric trends from abroad, the scholarly coverage is very uneven. Some major currents, and the scholarly work that has been done on them, will be briefly surveyed here.

Somewhat surprisingly, fin-de-siècle occultism in Scandinavia is a virtually unexplored field of research in terms of both international and local occultist organisations. For instance, both the Martinist Order and The Hermetic Brotherhood of Luxor were established at the end of the 19th century in Sweden. The Martinist Order was founded in 1891 by the French occultist Dr Gérard Encausse (1865-1916) together with Augustin Chaboseau (1868-1946), and their teachings derived to a large extent from the writings of Louis Claude de Saint-Martin (1743-1803) and Martinès de Pasqually (d. 1774). Allegedly, the Martinist Order had no less than seven lodges in Sweden, and it was also, again allegedly, established in Norway and Denmark. The Hermetic Brotherhood of Luxor was established around 1884 and it was particularly active in the United States, England and France. This organisation was unusual in that it stressed the importance of the practical side of occultism whereas the majority of occultist organisations at the turn of the last century had a more philosophical and theoretical approach. What is particularly conspicuous about The Hermetic Brotherhood of Luxor in Sweden is that it cooperated with the Theosophical Society, something which was very unusual in other countries. In fact, beginning in 1898, a journal entitled Psyche, later Aur, Tidskrift for Esoteriskt Studium (Psyche/Aur, Journal for Esoteric Studies) was published exclusively for the benefit of the members of the spiritualist organisations, the Martinist Order, the Theosophical Society, The Hermetic Brotherhood of Luxor, The Temple, The Universal Brotherhood, as well as the F.M.O. (the latter probably an abbreviation for Fri-Murare Orden, most likely some form of irregular Freemasonry). The journal was published at least up to 1910.

There are and have been a number of magical and occultist movements in the Scandinavian milieu. In Sweden, Dragon Rouge (Ordo Draconis et Atri Adamantis) stands out as one of the most well-known occultist movements. Founded in 1989 by a group of teenagers in Stockholm, it quickly caught the attention of the media which labelled it a satanic group. By the mid-90s, the movement had established itself throughout Sweden and its membership exceeded 500 people, which is a comparatively high number for a Swedish alternative spiritual organisation. During the second half of the 1990s, Dragon Rouge became less visible in the mass media and its membership dwindled. However, this period was also characterised by an increasing maturity of the organisa- 
tion: stricter rules for local lodges were created, and a wealth of written material was produced for the members. Today, Dragon Rouge has established lodges in countries such as Germany, Poland and Italy and is thus the first Swedish occultist new religious movement to become an international movement.

Dragon Rouge is often described as a left hand path organisation. The practical aspect of the left hand path, as defined by Dragon Rouge, is antinomianism. A key idea within the movement is that man is bound, and thereby restricted, by unconscious norms and values. In order to progress spiritually it is necessary to free oneself from these unconscious bonds, and create conscious norms and ideals instead. The antinomianism of Dragon Rouge can thus be interpreted as a way of becoming conscious of aspects that are buried in the unconscious. In practice, this is achieved through the use of symbols that are normally interpreted as evil or destructive. According to Dragon Rouge doctrine, antinomianism is the means to accomplish self-deification. Man is potentially divine, and it is only when he or she becomes divine that free will can be reached. Using this free will, it is believed that the disciple is able to create his or her own universe, thereby becoming not only a god, but a god of creation or demiurge. The goal of the initiatory system of Dragon Rouge is thus not an end in itself (self-deification) but merely the beginning of a new process of creation that takes place according to the will of the magician. Dragon Rouge has been documented in one recent dissertation by Kennet Granholm, Embracing the Dark (2005).

The 1990s saw the establishment of a number of international occultist organisations in Scandinavia, including Ordo Templi Orientis, The Hermetic Order of the Golden Dawn, Servants of the Light, and Temple of Set, and a number of indigenous pagan organisations were also founded in this period (although paganism in Scandinavia goes back at least to the 1970s). Apart from Granholm's thesis relatively little research has been done on these occultist movements in Sweden.

Scandinavian Enlightenment and Romantic esotericism have received very little attention from scholars publishing in any major language. In Swedish, however, there is a body of scholarship dating back to the early twentieth century. In 1916, Albert Nilsson published Svensk Romantik: Den Platonska strömningen (Swedish Romanticism: The Platonic Current), where he surveyed the interest in what he called 'mystical Platonism'. Esotericism as a concept did not exist for Nilsson, who surveyed his material as a literary and philosophical current. In 1918-20 the aforementioned Martin Lamm published his two-tome work Upplysningens romantic (The Romanticism of the Enlightenment), 
in which he pushed the chronology further back. The idea that the Enlightenment also comprised a mystical component, today particularly explored in the German realm by Monica Neugebauer-Wölk, can be found fully formed in this work from nearly a century ago.

Despite his intellectual roots in literary criticism, Lamm viewed Enlightenment 'mysticism' as a current of cultural and intellectual history, and explicitly not as a specifically literary current. Nevertheless, it is the literary expression that is privileged in Lamm's work. Again, for Lamm, the term esotericism is not part of his analytic vocabulary; his mystical Enlightenment includes not only such clearly 'esoteric' themes as Masonry, but also more general pre-Romantic and Rousseauan elements such as an anti-modernist primitivism (in which the Scythians, surprisingly, are singled out as examples), a cult of nature, a predilection for the emotions, and a belief in the goodness of the individual unspoilt by the corrupting influences of education.

Mesmerism, Lamm suggests, is a crucial component of 'Enlightenment mysticism'; nevertheless it remains a less central part of Lamm's oeuvre, perhaps precisely because it is not concerned so much with literature, art and ideas, as with praxis. The topic was to be dealt with extensively in Karin Johannisson's doctoral dissertation Magnetisörernas tid: den animala magnetismen $i$ Sverige, completed in 1974 (The Age of Mesmerizers: Animal Magnetism in Sweden). Johannisson documents the early reception of mesmerism and its cultural and social importance in Sweden. Mesmerism entered a cultural climate already primed by Swedenborg to accept the existence of an invisible realm accessible to those whose senses had been heightened. Newspaper reports as early as the late 1770s prepared the way for the first visit by a French mesmerist, a certain M. Marais, in 1785. Mesmerism spread not least via an institutionalized Exegetic and Philanthropic Society, founded as early as 1786. Johannisson's dissertation highlights the importance of Per Gustaf Cederschjöld (1782-1848), Professor of Medicine at the prestigious Karolinska Institute. A range of apparently paranormal phenomena described in German mesmerist literature appear in his treatments, from clairvoyance to the presumed contact with a spirit world.

Literary historians have also documented the main esoteric current of the Swedish Romantic era, the New School. The leading spokespersons of the New School were a group of writers centred on the poet Per Daniel Amadeus Atterbom (1790-1855). German Romanticism provided a common frame of reference for the group. Schelling's philosophy inspired a characteristically Romantic picture of man as a creature whose connection with nature, once whole and immediate, was now broken. 
Beginning shortly before 1810, they proclaimed the rise of a new age in which poet-prophets endowed with the ability to enter into a higher state could decode the manifestations of the divine in the everyday world, and bring about the reintegration of man. The circle of writers was united by their youth and their shared sense of opposition against a previous generation of authors who, they felt, were far too heavily influenced by the Enlightenment, an epoch and a way of writing and thinking for which they felt nothing but contempt. Atterbom, who wrote a programmatic statement of the New School, polemically characterized the Enlightenment as the work of 'dwarfs, polluting the lyre of genius'. As a symbol of their self-perception as a new and different breed of writers, many of their literary as well as their programmatic texts were published in their own short-lived journals, of which the two most important were Polyfem (1809-12) and Phosphoros (1810-13).

Whereas somewhat older currents have been viewed with interest by an earlier generation of scholars, much of the literature on later currents, i.e. forms of esotericism dating roughly from the last decades of the nineteenth century to the present day, is marked by a polemic tone. What is acceptable as long as it is conveyed in literary works is regularly presented as 'pseudo-religious' or absurd when found in later currents. Many works on theosophy, spiritualism or anthroposophy in Sweden polemicize rather than study these phenomena. This trend begins to change in the 1990s, with the appearance of more academically neutral studies.

The historian of ideas Inga Sanner discusses spiritualism and theosophy in her book Att älska sin nästa såsom sig själv: om moraliska utopier under 1800-talet (Loving One's Neighbour as Oneself: On Moral Utopias in the Nineteenth Century), published in 1995. Both currents are selectively examined, since the focus of interest of Sanner's book is what she defines as moral utopias.

Theosophy and anthroposophy become better documented in a doctoral dissertation by Håkan Lejon, Historien om den antroposofiska humanismen (The Story of Anthroposophical Humanism), published in 1997. Lejon demonstrates the importance of the theosophical and anthroposophical movements in Sweden. Theosophy was known in Sweden via public lectures (from 1887) and newspaper articles (from 1889), and a lodge was established in 1889. The self-understanding of theosophy as 'oriental wisdom' made it popular also in Sweden, which had a strong 'orientalist' current.

Theosophy spread by way of intense marketing: books were translated into Swedish; the co-founder of the Theosophical Society Henry 
S. Olcott visited Stockholm in 1891. As the Society increasingly experienced rivalries between the Adyar and American factions, many Swedes sided with the Americans. The theosophists split into two distinct organizations, and the American branch, then led by Katherine Tingley, was so prominent in Sweden that the island of Visingsö was selected as the location of a major European centre. A major theosophical peace conference was held there in 1913.

In the same year, the schism took place that established the Anthroposophical Society as a distinct organization, headed by Rudolf Steiner. Soon after the split occurred in Germany, a number of Swedish lodges joined the anthroposophists. Already in January 1913, the Secretary General of the Swedish Theosophical Society resigned and came to lead the new, anthroposophical organization. In Denmark, the situation was even more acute: the entire Copenhagen lodge left the theosophical mother organization and joined the anthroposophists.

Most contemporary esoteric movements are only scantily documented. Among the theosophically inspired movements found in Scandinavia, Summit Lighthouse can be mentioned, and the network of people interested in the writings of Alice Bailey. In both cases, there is no scholarly literature at all. The same can be said of the reception and influence of Jung's ideas in Scandinavia, a subject on which there is a considerable amount of partisan literature but no scholarship at all.

The loose form of religiosity often subsumed under the umbrella term 'New Age' is better documented. There are, for example, general and historical overviews, sociological studies, more specialized surveys of the role of alternative medicine, and a field-based investigation of the role of astrology. We have seen how many forms of early esotericism in Sweden were connected to the social and intellectual elites. Although New Age religiosity remains a topic viewed with scepticism by intellectuals, New Age thinking was to a considerable extent also ushered in through a channel representing the higher echelons of society. For a number of years, the major Swedish conservative daily newspaper Svenska Dagbladet featured articles on 'alternative' topics.

To conclude, several esoteric currents have played a significant role in the Swedish (and more broadly, Scandinavian) religious landscape, and have been endorsed by prominent individuals. In view of their influence, many of these currents are surprisingly understudied. At the time of writing, the authors of the present article are editing an Englishlanguage encyclopaedic survey with contributions by nearly all scholars working on esotericism in Denmark, Finland, Norway and Sweden, covering practically all major esoteric currents in these countries. This 
survey, which is expected to appear in print in 2010, will integrate the study of Scandinavian esotericism into the field as a whole.

\section{References}

\section{Åkerman, Susanna}

1998 Rose Cross over the Baltic: the Spread of Rosicrucianism in Northern Europe. Leiden, Boston: Brill.

\section{Bogdan, Henrik}

2007 Western Esotericism and Rituals of Initiation. Albany: SUNY Press.

\section{Edenborg, Carl-Michael}

2002 Alkemins skam: den alkemiska traditionens utstötning ur offentligheten. Stockholm: Caudex.

\section{Granholm, Kennet}

2005 Embracing the Dark. Åbo: Åbo Akademi University.

Hanegraaff, Wouter et al. (eds)

2005 Dictionary of Gnosis and Western Esotericism. Leiden, etc.: Brill.

Johannisson, Karin

1974 Magnetisörernas tid: den animala magnetismen i Sverige. Stockholm: Lychnos Bibliotek.

\section{Karlsson, Thomas}

2005 Adulrunan. Sundbyberg: Ouroboros.

\section{Lamm, Martin}

1918-20 Upplysningens romantik I-II. Stockholm: Hugo Gebers förlag.

\section{Lejon, Håkan}

1997 Historien om den antroposofiska humanismen: den antroposofiska bildningsidén i idéhistoriskt perspektiv 1880-1980. Stockholm: Almqvist \& Wiksell.

\section{Nilsson, Albert}

1916 Svensk Romantik: den Platonska strömningen. Lund: Gleerup.

\section{Önnerfors, Andreas}

2003 Svenska Pommern - kulturmöten och identifikation 1720-1815. Lund: Avd. för idé- och lärdomshistoria, Lunds universitet.

\section{Sanner, Inga}

1995 Att älska sin nästa såsom sig själv: om moraliska utopier under 1800-talet. Stockholm: Carlsson.

\section{Simonsen, Anders}

2001 Bland hederligt folk-organiserat sällskapsliv och borgerlig formering $i$ Göteborg 1755-1820. Göteborg: Historiska institutionen, Göteborgs universitet.

\section{Stenius, Henrik}

1987 Frivilligt, jämlikt, samfällt: Föreningsväsendets utveckling $i$ Finland fram till 1900-talets början med speciell hänsyn till massorganisationsprincipens genombrott. Helsingfors: Svenska litteratursällskapet i Finland. 